\section{Biletska Y. Bakirov M., Polupan V.}

\title{
INFLUENCE OF DIFFERENT CONCENTRATIONS OF LEGUME FLOUR ON THE VOLUME OF EXTRACTED WHEY IN SOUR MILK PRODUCT
}

The object of research is fermented milk products based on goat milk, produced by the thermostatic method. The effect of legume flour with the introduction of 1.5; 2.0; 2.5\% by weight of the fermented milk product on the volume of extracted whey formed during a certain centrifugation time of fermented milk product is studied. One of the most problematic areas is that when the recipe ingredients change, even in unknown quantities, their rheological characteristics change. Technological approaches applied by scientists simultaneously with product enrichment change its organoleptic characteristics, thereby reducing the demand for the developed products. The food soy flour, enriched with iodine, and food chickpea flour, enriched with selenium, are used. The study of the volume of extracted whey in the fermented milk product is determined by syneresis analysis. It has been established that the use of legume flour in the concentration range of 1.5-2.5\% by weight of the product affects the structure of the fermented milk product towards its stabilization. Directly proportional dependence to the percentage of flour application is determined. A sample with a legume flour concentration of $2.5 \%$ by weight of the product has the lowest percentage of extracted whey, since the curd in this sample is denser. This is due to the fact that during the joint use flour of legumes and microorganisms in goat milk, lactose decomposes, which, acting on calcium caseinate, replaces it with hydrogen, as a result of which denser fermented milk clot is formed.

Compared to analogs of fermented milk products for special dietary nutrition, the use of legume flour provides such advantages as the usual structure and consistency of the product, and also covers the daily requirement for iodine from 12.6 to $21 \%$ and the daily requirement for selenium from 18.4 to $30.6 \%$.

Keywords: legume flour, fermented milk product, iodine-deficiency, selenium-deficiency, soybeans, chickpea beans.

Received date: 03.04.2020

Accepted date: 13.05 .2020

Published date: 31.08 .2020
Copyright (C) 2020, Biletska Y., Bakirov M., Polupan V. This is an open access article under the CC BY license (http://creativecommons.org/licenses/by/4.0)

\section{Introduction}

In the modern concept of healthy eating, a special role belongs to products for special dietary consumption [1-3]. These are products that are made with safe food ingredients, high in vitamins and essential micronutrients, and can and should be included in the daily diet of a person. Fermented milk products are a product of daily consumption in the diets of people with various diseases [4-6].

A characteristic feature of fermented milk products is that when the recipe ingredients change even in small amounts, their rheological characteristics change [7, 8]. Technological approaches used by scientists [9-11] in the development of technologies for fermented milk products for special purposes change their organoleptic characteristics, thereby reducing the demand for the developed products. The main quality indicators from the general organoleptic indicators, which the consumer gives priority value, are the structure and consistency of the fermented milk product. The consumer prefers products with a dense fermented milk curd without excess liquid or extracted whey [12]. According to the normative and technical documentation [13], the percentage of extracted whey in a fermented milk product should be no more than $5 \%$ of the product volume. Therefore, the aim of this research is to study the effect of different concentrations of legume flour on the volume of extracted whey in a fermented milk product and to optimize the data obtained. This is relevant and timely and will expand the range of fermented milk products with familiar organoleptic characteristics. This is of particular value considering the possible use of the developed products in diets for people with special dietary nutrition.

The object of research is fermented milk products based on goat milk, produced by the thermostatic method.

\section{Methods of research}

There are used:

- fermented milk products based on milk from goats of the Zaanenska breed (Galaiky village, Kyiv region, Ukraine);

- microorganisms: Lactobacillus acidophilus, Bifidobacterium lactis, Lactobacillus delbrueckii ssp. Bulgaricus, Streptococcus thermophiles;

- «Soybean food meal enriched with iodine» TU U 10.60271205-001:2019, «Chickpea food meal enriched with selenium» TU U 10.6-0271205-002:2019. 
The effect of legume flour (in a ratio of 1:1) with the introduction of $1.5 ; 2.0 ; 2.5 \%$ by weight of the fermented milk product were investigated. Samples of the fermented milk product were prepared by the thermostatic method. Heated goat milk to $t=35-40{ }^{\circ} \mathrm{C}$. Soured at $t=40{ }^{\circ} \mathrm{C}$. Cooled to $t=(25 \pm 2)^{\circ} \mathrm{C}$. Acidity of fermented milk product samples using legume flour in an amount of $1.5 \%$ after $3,4,5$ hours of fermentation was $5.0 ; 4.8 ; 4.72 \mathrm{pH}$ units, respectively. The acidity of the samples using legume flour in an amount of $2 \%$ after 3, 4, 5 hours of fermentation was $4.96 ; 4.76 ; 4.69 \mathrm{pH}$ units, respectively. The acidity of samples with legume flour in the amount of $2.5 \%$ after $3,4,5$ hours of fermentation reached $4.8 ; 4.70 ; 4.66 \mathrm{pH}$ units, respectively. The fermentation time was from 0 to 6 hours. The study of the volume of extracted whey in the fermented milk product was determined by syneresis analysis. The volume of extracted whey, formed during a certain time of centrifugation of a fermented milk product, was analyzed. Data optimization was carried out using the MathCad program.

\section{Research results and discussion}

Fig. 1 shows the effect of different concentrations of legume flour on the volume of extracted whey in a fermented milk product.
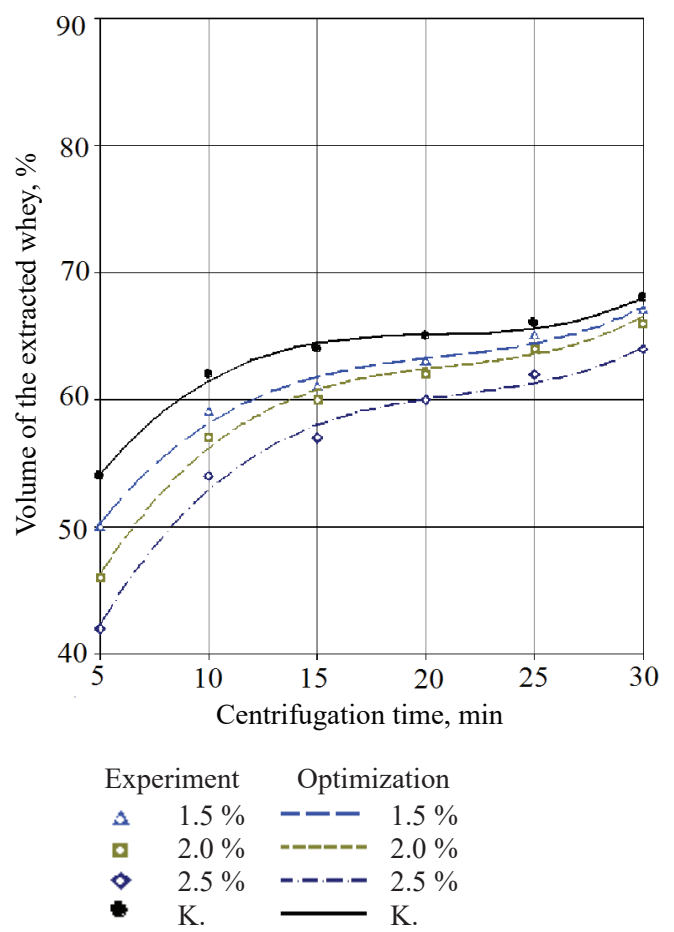

Fig. 1. Influence of different concentrations of legume flour on the volume of extracted whey in a fermented milk product

It has been established that the use of legume flour in the concentration range of $1.5-2.5 \%$ by weight of the product affects the structure of the fermented milk product towards its stabilization. Directly proportional dependence to the percentage of flour application is determined. A sample with a legume flour concentration of $2.5 \%$ by weight of the product had the lowest percentage of extracted whey, since the curd in this sample is denser. Let's assume that during the joint use of flour of legumes and microorganisms in goat milk, lactose decomposes, which, acting on calcium caseinate, replaces it with hydrogen, resulting in a denser fermented milk clot [14].

Using the correlation-regression analysis, the mathematical dependences reflecting the change in acidity $(y)$ from the duration of fermentation $(x)$ with an amount of $1.5 ; 2.0 ; 2.5 \%$ legume flour in the range of fermentation duration (0-6 hours) are obtained:

- for a sample of a fermented milk product using $1.5 \%$ flour of sprouted legumes:

$y^{1}=17.364+10.365 x+2.245 x^{2}-0.328 x^{3} ; R^{2}=0.951$

- for a sample of a fermented milk product using $2 \%$ flour of sprouted legumes:

$y^{2}=18.758+11.357 x+2.067 x^{2}-0.318 x^{3} ; R^{2}=0.961 ;$

- for a sample of a fermented milk product using $2.5 \%$ flour of sprouted legumes:

$$
y^{3}=18.712+15.591 x+0.807 x^{2}-0.215 x^{3} ; R^{2}=0.973
$$

Use of a legume flour with an introduction rate of $1.5 ; 2.0 ; 2.5 \%$ by weight of the fermented milk product will positively affect the consistency of the product and the density of its fermented milk curd. Products with the aforementioned concentrations cover the daily iodine requirement by $12.6 ; 16.8 ; 21 \%$ (respectively) and the daily requirement for selenium by $18.4 ; 24.5 ; 30.6 \%$ (respectively).

\section{Conclusions}

The effect of various concentrations of legume flour on the volume of extracted whey in a fermented milk product was studied and the data obtained were optimized. On the basis of these data, it was found that the use of legume flour in the concentration range of $1.5-2.5 \%$ by weight of the product affects the structure of the fermented milk product towards its stabilization. Directly proportional dependence to the percentage of flour application is determined. A sample with a legume flour concentration of $2.5 \%$ by weight of the product has the lowest percentage of extracted whey, since the curd in this sample is denser. Products with the above concentrations cover the daily iodine requirement by $12.6 ; 16.8 ; 21 \%$ (respectively) and the daily requirement for selenium by $18.4 ; 24.5 ; 30.6 \%$ (respectively).

\section{References}

1. Biletska, Y., Plotnikova, R., Danko, N., Bakirov, M., Chuiko, M., Perepelytsia, A. (2019). Substantiation of the expediency to use iodine-enriched soya flour in the production of bread for special dietary consumption. Eastern-European Journal of Enterprise Technologies, 5 (11 (101)), 48-55. doi: http://doi.org/ 10.15587/1729-4061.2019.179809

2. Biletska, Y., Plotnikova, R., Skyrda, O., Bakirov, M., Iurchenko, S., Botshtein, B. (2020). Devising a technology for making flour from chickpea enriched with selenium. Eastern-European Journal of Enterprise Technologies, 1 (11 (103)), 50-58 doi: http://doi.org/10.15587/1729-4061.2020.193515

3. Biletska, Y., Djukareva, G., Ryzhkova, T., Kotlyar, O., Khaustova, T, Andrieieva, S., Bilovska, O. (2020). Substantiating the use of germinated legume flour enriched with iodine and selenium in the production of cooked-smoked sausages. Eastern-European Journal of Enterprise Technologies, 3 (11 (105)), 46-54. doi: http:// doi.org/10.15587/1729-4061.2020.204796 
4. El-Salhy, M., Mazzawi, T., Hausken, T., Hatlebakk, J. G. (2016). Interaction between diet and gastrointestinal endocrine cells. Biomedical Reports, 4 (6), 651-656. doi: http://doi.org/10.3892/ br.2016.649

5. Hannah, W. N., Harrison, S. A. (2016). Lifestyle and Dietary Interventions in the Management of Nonalcoholic Fatty Liver Disease. Digestive Diseases and Sciences, 61 (5), 1365-1374. doi: http://doi.org/10.1007/s10620-016-4153-y

6. Pace, L. A., Crowe, S. E. (2016). Complex Relationships Between Food, Diet, and the Microbiome. Gastroenterology Clinics of North America, 45 (2), 253-265. doi: http://doi.org/10.1016/ j.gtc.2016.02.004

7. Lobuckaia, N. V., Dediukhina, V. P., Pavlova, Zh. P., Ermak, I. M. (2004). Vliianie protosimbeoticheskikh smesei chistykh kultur molochnokislykh bakterii na formirovanie molochnykh zgustkov pri proizvodstve irgurtov. Izvestiia Dalnevostochnogo federalnogo universiteta. Ekonomika i upravlenie, 78-83.

8. Ryzhkova, T., Bondarenko, T., Dyukareva, G., Biletskaya, Y (2017). Development of a technology with an iodine-containing additive to produce kefir from goat milk. Eastern-European Jour nal of Enterprise Technologies, 3 (11 (87)), 37-44. doi: http:// doi.org/10.15587/1729-4061.2017.103824

9. Krupicyn, V. V., Ponomareva, I. N., Shilov, Iu. A., Ryzhkov, E. I. (2016). Assessment of quality and microbiological parameters of yogurts enriched with propolis. Vestnik of voronezh state agrarian university, 48 (1), 148-155. doi: http://doi.org/10.17238/ issn2071-2243.2016.1.148

10. Beliakova, S. Iu., Krasnikova, L. V. (2014). Sinbioticheskie kislomolochnye produkty s rastitelnymi napolniteliami dlia pitaniia detei shkolnogo vozrasta. Nauchnii zhurnal NIU ITMO. Seriia «Processy $i$ apparaty pischevykh proizvodsto», 1. Available at: https://cyberleninka.ru/article/n/sinbioticheskie-kislomolochnye-produkty-s-rastitelnymi-napolnitelyami-dlya-pitaniya-detey-shkolnogo-vozrasta-1
11. Uskova, D. G., Popova, N. V. (2019). The study of storage stability of yoghurt made on the basis of sonochemical micronized fucoidan. Bulletin of the South Ural State University Series Food and Biotechnology, 7 (2), 24-34. doi: http://doi.org/ $10.14529 /$ food 190203

12. Kanareikina, S. G., Kanareikin, V. I. (2016). Razrabotka lineiki molochno-rastitelnykh iogurtov. Izvestiia Orenburgskogo gosudarstvennogo agrarnogo universiteta, 100-103.

13. Pro zatverdzhennia Pravyl veterynarno-sanitarnoi ekspertyzy moloka $i$ molochnykh produktiv ta vymoh shchodo yikh realizatsii (2004). Nakaz Ministerstvo ahrarnoi polityky Ukrainy derzhavnyi departament veterynarnoi medytsyny No. 49. 20.04.2004. Available at: https://zakon.rada.gov.ua/go/z0579-04

14. Temerbaeva, M. V., Bekseytov, T. K. (2017). Razrabotka tekhnolohy byoiohurta dlia funktsionalnoho pytanyia na osnove kozeho moloka. Vestnyk Omskoho HAU, 1 (25), 120-126.

Biletska Yana, PhD, Department of International E-commerce and Hotel and Restaurant Business, V. N. Karazin Kharkiv National University, Ukraine, e-mail: ya.belecka@karazin.ua, ORCID: http:// orcid.org/0000-0001-8060-6579

Bakirov Myushfik, PhD, Department of Hotel and Restaurant Business and Merchandise, University of Customs and Finance, Dnipro, Ukraine, e-mail: bakirov_mp@ukr.net, ORCID: http://orcid.org/ 0000-0001-9723-9808

Polupan Vadim, PhD, Department of Commodity Science in Customs Kharkiv State University of Food Technology and Trade, Ukraine, e-mail: polupan.v@ukr.net, ORCID: http://orcid.org/0000-00024729-6107 